\title{
Drought stress monitoring by laboratory and satellite spectral methods in an apple orchard
}

\author{
Nagy, A., Riczu, P. \& Tamás, J. \\ University of Debrecen, Institute of Water and Environmental Management, \\ Debrecen, 4032 Böszörményi str. 138.
}

\begin{abstract}
Summary: An orchard can be examined on the basis of spectral data, using such methods with which the reflected radiation can be divided into a large number of (several hundreds) small spectral channel (some nm). Based on the spectral characteristics of the canopy, or the different index numbers calculated from hyperspectral data the water supply conditions of foliage can be well characterized. The research site is an intensive apple orchard, which located in Debrecen University, Centre for Agricultural and Applied Economic Sciences, Farm and Regional Research Institute at Pallag. During our experiments the evaluation of spectral, non-invasive measurement method are carried out for detecting stress symptoms caused by drought. Furthermore, MODIS NDVI time series data were analyzed for orchards situated in NorthEastern part of Hungary in drought effected and wet years in order to detect differences. Significant differences in NDVI values were detected after the end of June.
\end{abstract}

Keywords: water content, drought stress, spectral measurements

\section{Introduction}

Drought adaptation has a special significance in modern biomass production, in order to reduce production risks, to mitigate extreme water stress situations and to enhance food and crop safety. These goals can only be achieved by integrated complex approach in crop and fruit production as well as rural development (Juhász et al. 2013). Hungary has favourable agro ecological potential for pomaceous fruit production (Soltész \& Szabó 1998). Orchards are relatively not highly water consumer comparison with cereal species. However, to ensure optimal water capacity values calculating breeding season it is the most important risk factor. Therefore in large orchards up-to-date information is needed on water capacity and possible water stress of the fruit trees. The reason for this is that the physiological reactions against the changing water capacity appear much earlier than the water stress. These physiological changes cannot be observed visually in the early period of water stress. Thus early detection of the effect of different stressors, such as drought has a key role in the mitigation and prevention.

The chlorophyll content is one of the indicators of the state of health (Burai et al. 2009), which affect the reflectance spectra of the vegetation and the vegetation indices as well. Minimum at the visible spectral range is related to pigments in plant leaves. Chlorophyll absorbs markedly spectral range between $450-670 \mathrm{~nm}$. Healthy vegetation reflects the $40-50 \%$ of the incoming energy between $700-1300 \mathrm{~nm}$ spectral ranges due to the internal structure of the canopy, lignin content and parenchyma structure of the leaves (Gates et al.,
1965). In this way, the measured reflectance plays an important role in distinguishing different plant species and possible water stress, even if these species are seems to be similar based on visible spectral range (Berke et al., 2004). In reference to this, searching areas referring to early recognisability of plant diseases, mapping of deficiency of nutrients by reflectance spectrum, the singular or association level approach of the vegetation in agro-ecological, cropping technologies respect, have to be mentioned (Santoso et al, 2011).

The development of remote sensing techniques and the new generation of satellite and airborne sensors could give advanced tools for analysing the biomass productivity in different space and time. Products of new generation of satellite and airborne sensors could give advanced tool for end users to produce new drought related products. The NASA and the U.S. Department of Agriculture Foreign Agricultural Service (USDA FAS) jointly funded a new project to assimilate NASA's Moderate Resolution Imaging Spectroradiometer (MODIS) data and in monitoring crop conditions for a specific region, remotely sensed vegetation index data can be use to track the evolution of the growing season compared to reference long-term mean conditions (Tucker, 1985).

\section{Materials and methods}

The field survey was carried out at the University of Debrecen, Centre for Agricultural and Applied Economic Sciences, Research Institute for Farm and Regional Research Sciences at Pallag. The examination site is a mi- 
croirrigated intensive apple orchard. All species were grafted on M9 stocks. Leaf samples were taken from the following apple species: Golden Reinders, Early Gold, Gala Galaxy, Gala Must, Pinova, Buckeye Gala, Gala Annaglo and Golden B from branches at $120 \mathrm{~cm}$ height, from five trees/species.

Goal of this study was to elaborate the spectral detectability of leaf characteristics concerning water stress. In order to achieve this goal, not only the spectral profiles of the leaf samples were measured, but also conventional gravimetric method for water content were carried out as a calibration for the spectral features. The spectral profiles (reflectance) were measured by laboratory scale AvaSpec 2048 spectrometer at 400-1000 nm wavelength interval with $0.6 \mathrm{~nm}$ spectral resolution. The AvaSpec 2048 system consists of one spectrometer, AvaLight-HAL halogen light source which are joined by a fibre optic with $8 \mu \mathrm{m}$ diameter and a self-innovated special sampling box in order to provide dark for measurements. The principal component analysis and bivariate correlation statistical methods were used to select that wavelength which relates to water content. Tukey variance analysis was used to determine the differences between different water content and detect spectral differences. Furthermore, MODIS NDVI time series data were analyzed for orchards situated in NorthEastern part of Hungary in drought effected (2007) and wet (2010) years in order to detect differences.

\section{Results}

The spectral profiles of apple leaves describe properly the spectral characteristics of healthy green vegetation (Figure 1) Chlorophyll absorbs markedly the electromagnetic radiations at $450-670 \mathrm{~nm}$ wavelength interval, especially at green and red color intervals. At $700 \mathrm{~nm}$ the reflectance increases steadily, and the leaves reflect the $60-80 \%$ of the light source energy between $700-1000 \mathrm{~nm}$ spectral ranges. It can also be stated, that due to the noise of the measurements, but mainly to the thinness of the leaf samples, spectral differences are not observed in water sensitive 900-970 nm wavelength interval (Champagne et al. 2001), thus it is not possible to calculate the well-known Water Band Index. Therefore, other wavelength intervals were studied for water sensitive.

Comparing the reflectance properties to dry material content of leaf samples significant correlation can be found at $540-575 \mathrm{~nm}(\mathrm{r} \sim-0.610)$ as well as $750-830 \mathrm{~nm}(\mathrm{r} \sim 0.8)$ (Figure 2).

Generally more water in tissues results larger absorbance and less reflectance. But in the 540-575nm interval inverse ratio was found, it is probably due to chlorophyll content, since the characteristics of healthier vegetation is not only observed by more water content, but also the chlorophyll content, which has high reflectance properties at the concerned spectral interval. On the other hand, at NIR spectral range the reflectance increases as the dry material content grows, due to the water content changes and the changes of

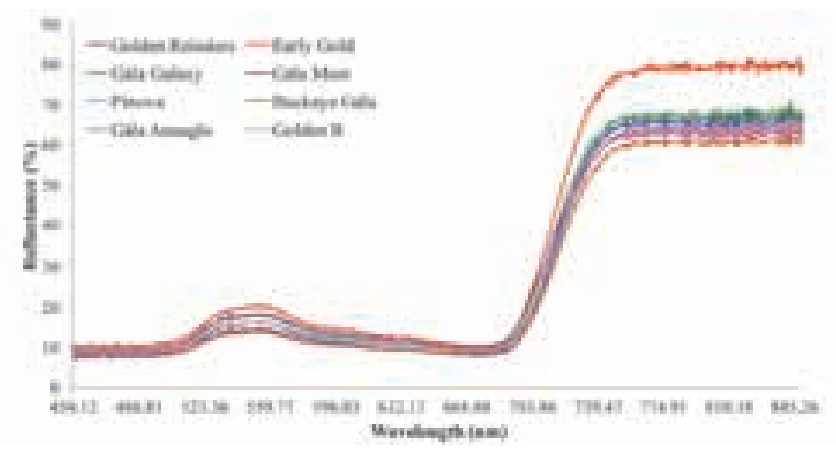

Figure 1. Spectral profiles of the apple species

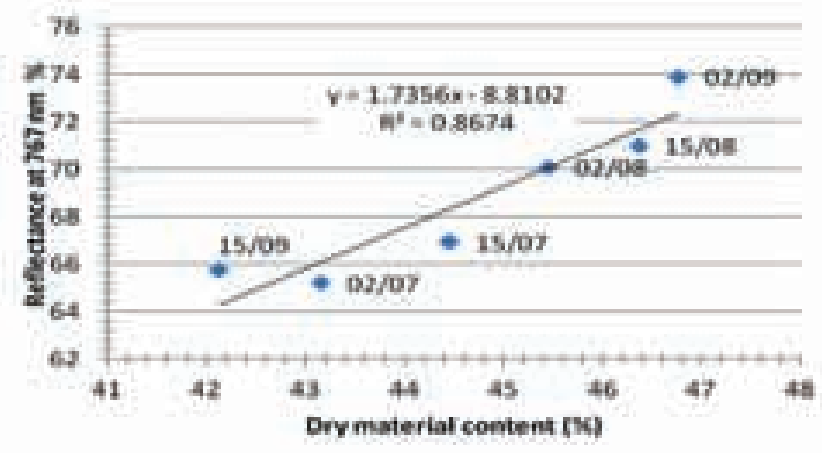

Figure 2. Correlation between reflectance at a specified spectrum with dry material content

the internal structure of the leaves. Therefore, in the case of this spectral measurement method NIR spectral interval (750-830) should be used for water content and water stress detection in leaves.

Examining phenologic phases of the apple trees, the water content of the leaves is permanently decreased. On the other hand, there were some exceptions in the case of several apple species. Small decrease in dry material content was observed in leaves sampled in September. Based on the Tukey variance analysis, these changes were significant. These significant changes were also detected in the case of several wavelengths in NIR range as well. (Table 1). This also suggest to use the NIR range $(750-30 \mathrm{~nm}$ ) for water content detection and water stress analysis of trees.

Table 1. Changing of dry material content in the vegetation period based on Tukey variance analysis

\begin{tabular}{|c|c|c|}
\hline Time series & $\begin{array}{c}\text { Dry material content } \\
(\boldsymbol{\%})\end{array}$ & $\begin{array}{c}\text { Reflectance } \\
\text { At 767 } \mathbf{~ m m}\end{array}$ \\
\hline $02 / 07$ & $41.65^{\mathrm{a}}$ & $63.77^{\mathrm{a}}$ \\
\hline $15 / 07$ & $46.47^{\mathrm{b}}$ & $67.30^{\mathrm{ab}}$ \\
\hline $02 / 08$ & $46.47^{\mathrm{b}}$ & $69.57^{\mathrm{ab}}$ \\
\hline $15 / 08$ & $43.54^{\mathrm{c}}$ & $74.15^{\mathrm{b}}$ \\
\hline $02 / 09$ & $43.18^{\mathrm{ac}}$ & $69.87^{\mathrm{ab}}$ \\
\hline $15 / 09$ & $41.88^{\mathrm{a}}$ & $65.29^{\mathrm{a}}$ \\
\hline
\end{tabular}

*no significance differences within values labeled by the same letter $(\mathrm{P}<0.05)$ 
The reason for small decrease in dry material content is the weather. There were no significant precipitation in July and August before the sampling, but in September 10-15 mm precipitation has fallen, which increased the water content of the leaf samples.

Analysing of the drought affected years, in the case of orchards drought can appear at the middle of June in the Southern part of the counties. On the other hand in wet years the higher NDVI values were detected representing good water supply circumstances. In July NDVI values were about 0.5 0.6 in 2007, meanwhile 0.6-0.8 in 2010, and in August the average difference NDVI was 0.3-0.4 (Figure 3).

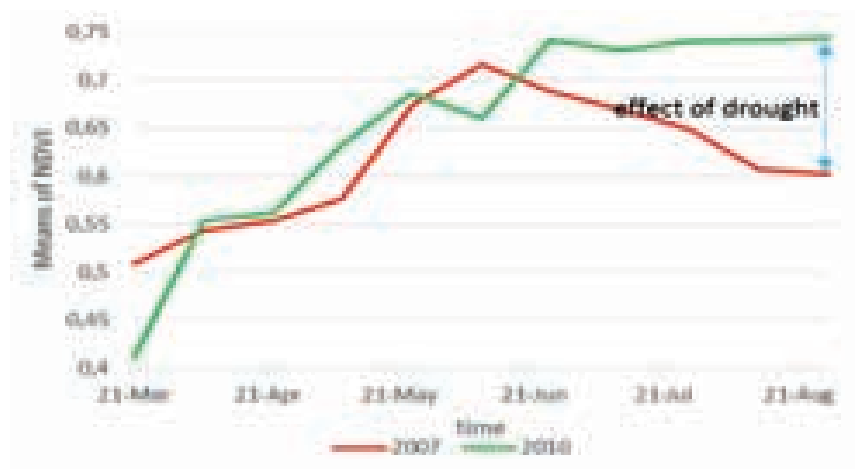

Figure 3. Average NDVI values in a wet and a dry year

Beside lack of precipitation several other factors can significantly influence the yield. These factors are mostly climatic. In some of the examined years there were severe freeze damages in early spring, which caused decrease in yield. Another typical problem in summer is the hail damages. There was special circumstance in 2010, when the amount of precipitation was nearly twice as much as the long term average annual precipitation, thus the effect of excess water and pathogen agents had also negative effect.

\section{Conclusion}

The spectral profiles of apple leaves describe properly the spectral characteristics of healthy green vegetation, although spectral filtering is needed for proper examination. Even after filtering, Water Band Index can not be calculated from leaf reflectance data. For water stress detection 750-830 nm spectral interval in NIR range can be used. MODIS NDVI can be a solution for drought monitoring, but further studies are needed for certification.

\section{Acknowledgment}

This research was supported by the European Union and the State of Hungary, co-financed by the European Social Fund in the framework of TÁMOP 4.2.4. A/2-11-1-20120001 'National Excellence Program'.

\section{References}

Berke J, Kelemen D \& Szabó J (2004): Digitális képfeldolgozás és alkalmazásai. (Digital image processing and application). Georgikon-Kvark, Keszthely, Pictron Kft., Budapest

Burai P, Kovács E, Lénárt Cs, Nagy A \& Nagy I (2009): Quantification of vegetation stress based on hypersectral image processing. Cereal Research Communications. 37: 581-584.

Champagne C, Pattey E, Bannari A \& Stratchan IB (2001): Mapping Crop Water Status: Issues of Scale in the Detection of Crop Water Stress Using Hyperspectral Indices. In: Proceedings of the 8th International Symposium on Physical Measurements and Signatures in Remote Sensing, Aussois, France. 79-84 p.

Droppa M, Erdei S, Horváth G, Kissimom J, Mészáros A, Szalai J \& Kosáry J (2003): Növénybiokémiai és növényélettani gyakorlatok. Budapest

Gates DM, Keegan HJ, Schleter JC, Weidner VR (1965): Spectral properties of plants. Applied Optics. 4: 11-20.

Juhász Cs, Rátonyi T, Harsányi E, Nagy J \& Széles A (2013): Situation and development possibilities of irrigation in Hungary. Infrastruktura I Ekologia Terenów Wiejskich. Infrastructure and Ecology of Rural Areas. Polish Academy of Sciences. Cracow Branch. Commission of Technical Rural Infrastructure. 1 (3): 45-54.

Santoso H, Gunawan T, Jatmiko RH, Darmosarkoro W \& Minasny B (2011): Mapping and identifying basal stem rot disease in oil palms in North Sumatra with QuickBird imagery. Precision Agriculture. 12 (2): 233-248.

Soltész M \& Szabó T (1998): Alma. (Apple) [In: Soltész (eds): Gyümölcsfajta-ismeret és -használat.] Mezőgazdasági Kiadó, Budapest. Hungary. 119-155. 